First publ. in: Journal of Membrane Biology 172 (1999), pp. 77-88

\title{
Hydrophobic and Hydrophilic Radio-Iodination, Crosslinking, and Differential Extraction of Cell Surface Proteins in Paramecium tetraurelia Cells
}

\author{
M. Flötenmeyer, M. Momayezi, H. Plattner \\ Faculty of Biology, University of Konstanz, P.O. Box 5560, D-78434 Konstanz, Germany
}

\begin{abstract}
We combined widely different biochemical methods to analyze proteins of the cell surface of $P$. tetraurelia since so far one can isolate only a subfraction of cell membrane vesicles enriched in the GPI-anchored surface antigens ("immoblization" or "i-AGs"). We also found that i-AGs may undergo partial degradation by endogenous proteases. Genuine intrinsic membrane proteins were recognized particularly with lipophilic 5-[ $\left.{ }^{125} \mathrm{I}\right]$-iodonaphthalene-1-azide (INA) labeling which reportedly "sees" integral proteins and cytoplasmic cell membrane-associated proteins. With INA (+DTT), bands of $\leq 55 \mathrm{kDa}$ were similar as with hydrophilic iodogen (+DTT), but instead of large size bands including i-AGs, a group of 122, 104 and $94 \mathrm{kDa}$ appeared. Several bands of the non i-AG type are compatible with integral (possibly oligomeric) or associated proteins of the cell membrane of established molecular identity, as we discuss. In summary, we can discriminate between i-AGs and some functionally important minor cell membrane components. Our methodical approach might be relevant also for an analysis of some related protozoan parasites.
\end{abstract}

Key words: Cell membrane - Ciliates - Crosslinking - Iodination - Paramecium - Proteins

\section{Introduction}

Our goal was to obtain some biochemical baseline information on different components of the cell surface membrane of Paramecium cells since so far, with a very few exceptions, only proteins with a glycophosphatidylinositol-(GPI)-anchor or cell membrane fraction enriched in these components can be isolated. Taking into account

Correspondence to: $\mathrm{H}$. Plattner the widely different molecular constitutents and their functional implications, we combined a variety of different methods.

Generally the cell membrane consists not only of the lipid bilayer with integral proteins and internally and externally associated proteins, but some proteins can also be externally attached by a GPI-anchor [18]. In the particular case of Paramecium, the entire cell surface is covered by GPI-anchored surface variant antigen or "immobilization antigen" (i-AG), as reviewed by Jones [23], Prat et al., [37], Preer [39], and Schmidt [41]. The i-AGs contribute $\sim 3.5 \%$ to total cell protein and, thus, by far outnumber any other cell membrane proteins [27]. Though they may by far dominate in cell membrane fractions obtainable by the only protocol available [44] to a disturbing extent, the function of these i-AGs in Paramecium remains enigmatic $[6,13]$, and such proteins represent a serious challenge to some closely related parasitic protozoa [28]. In the Paramecium cell, surface AGs follow a complicated biosynthetic and degradative pathway [19] which also requires more detailed analysis.

The i-AGs belong to a multigene family with mutual intergenic [3] and interallelic [8] exclusion, only one type of $\mathrm{i}-\mathrm{AG}$ being expressed at a time [4, 45]. The i-AGs consist of one polypeptide chain with a remarkably high cysteine content of $\sim 10 \%[23,37]$ whose SHgroups are all involved in disulfide bond formation [23]. Their apparent molecular mass is reported as ranging between $\sim 230$ to $330 \mathrm{kDa}[7,23,37]$. The reasons for fragmentation of i-AGs during isolation have not yet een elucidated in much detail. The C-terminal GPI-anchor of i-AGs is inserted into the outer leaflet of the cell membrnane lipid bilayer $[2,9,10,11,12,13,14]$.

Our goals were to clarify conditions of fragmentation of i-AGs, to set a baseline for further protein analysis, and thus, to obtain access to less numerous but functionally important proteins of the surface of Paramecium 
cells, and to see whether correlation with formerly established molecular components (see Discussion) may have a chance. We combine widely different methods, including protein extraction, radio-iodination or crosslinking, as outlined in Figs. 1 and 2. In particular we compare $\left[{ }^{125} \mathrm{I}\right]$-labeling with either lipophilic 5-iodonaphthyl-1 azide (INA), as introduced by Bercovici and Gitler [5] and Schwaller et al. [42], or with hydrophilic iodogen according to standard methods. Analyses of related parasites may also profit from the methods once established, particularly since isolation of cell membranes on the basis of GPI-anchored proteins is selective and may involve membranes from many intracellular compartments, according to in situ labeling studies [19].

\section{Materials and Methods}

\section{Cell Cultures}

Paramecium tetraurelia 7S wild-type cells [46] obtained from the CNRS in Gif-sur-Yvette were cultivated at $25^{\circ} \mathrm{C}$ in a sterile medium [24]. Until reaching the early stationary phase the cells were harvested as previously described by Plattner et al. [33].

\section{Chemicals}

3-[(3-cholamidopropyl)dimethylammonio]-1-propanesulfonate $=$ CHAPS, Boehringer, Mannheim, Germany. E64 (L-transepoxysuccinyl-leucylamido-[4-guanidinobutan]), Calbiochem, LaJolla, CA. 5-Aminonaphthyl-1-azide, Fluka, Buchs, $\mathrm{CH}$, Aprotinin, TAME (p-tosyl-L-arginin-methylester-HCl), high molecular weight (MW) kit, polyethyleneglycol (P-3640), Sigma, Deisenhofen, Germany. Low MW kit, dextran T500, Pharmacia, Freiburg, Germany. Iodogen, 1,5difluoro-2,4-dinitrobenzene (DFDNB), ethylenglycol-bis[succinylimidylsuccinate] (EGS), N-hydroxysuccinimidyl-4-azidobenzoate (HSAB), Pierce, St. Augustin, Germany. $\left.\mathrm{Na}^{125} \mathrm{I}\right]$ carrier free, ICN, Eschwege, Germany. Pefabloc SC, Pepstatin A, Serva, Heidelberg, Germany. Leupeptin, Biomol, Hamburg, Germany. Bis-Tris, Roth, Karlsruhe, Germany. All other compounds listed in Materials and Methods were of reagent grade and obtained from local suppliers.

\section{ISOLATION OF SURFACE ANTIGENS}

An outline is given in Fig. 1. We largely followed the method by Preer [38] as refined by Jones [23] to prepare i-AGs. Briefly, 2 liters of cell culture $\left(\sim 2 \times 10^{3}\right.$ cell/ml $)$ were washed in Dryl's solution $(1 \mathrm{mM}$ $\mathrm{NaH}_{2} \mathrm{PO}_{4}, 1 \mathrm{~mm} \mathrm{Na} \mathrm{HPO}_{4}, 2 \mathrm{~mm} \mathrm{Na}$ citrate and $1 \mathrm{mM} \mathrm{CaCl}_{2}, \mathrm{pH}=$ 6.8). Then cells were kept suspended for $1 \mathrm{hr}$ in extraction medium $(12 \%$ ethanol, $7.7 \mathrm{~mm} \mathrm{NaCl})$ at $4^{\circ} \mathrm{C}$ and briefly centrifuged after incubation $\left(2 \mathrm{~min}, 180 \times g, 4^{\circ} \mathrm{C}\right)$. The supernatant was further processed by centrifugation $\left(5 \mathrm{~min}, 20,000 \times g, 4^{\circ} \mathrm{C}\right)$. From the resulting supernatant, proteins were precipitated by adding $\left(\mathrm{NH}_{4}\right)_{2} \mathrm{SO}_{4}$, up to $75 \%$ saturation, under constant stirring on ice for $3 \mathrm{hr}$. The precipitated material was centrifuged $\left(15 \mathrm{~min}, 10,000 \times \mathrm{g}, 4^{\circ} \mathrm{C}\right)$, resuspended in 6 $\mathrm{ml}$ distilled water, and dialyzed overnight against distilled water. Any precipitated material appearing during dialysis was removed by centrifugation. Protein concentrations were determined by the Bradford method.

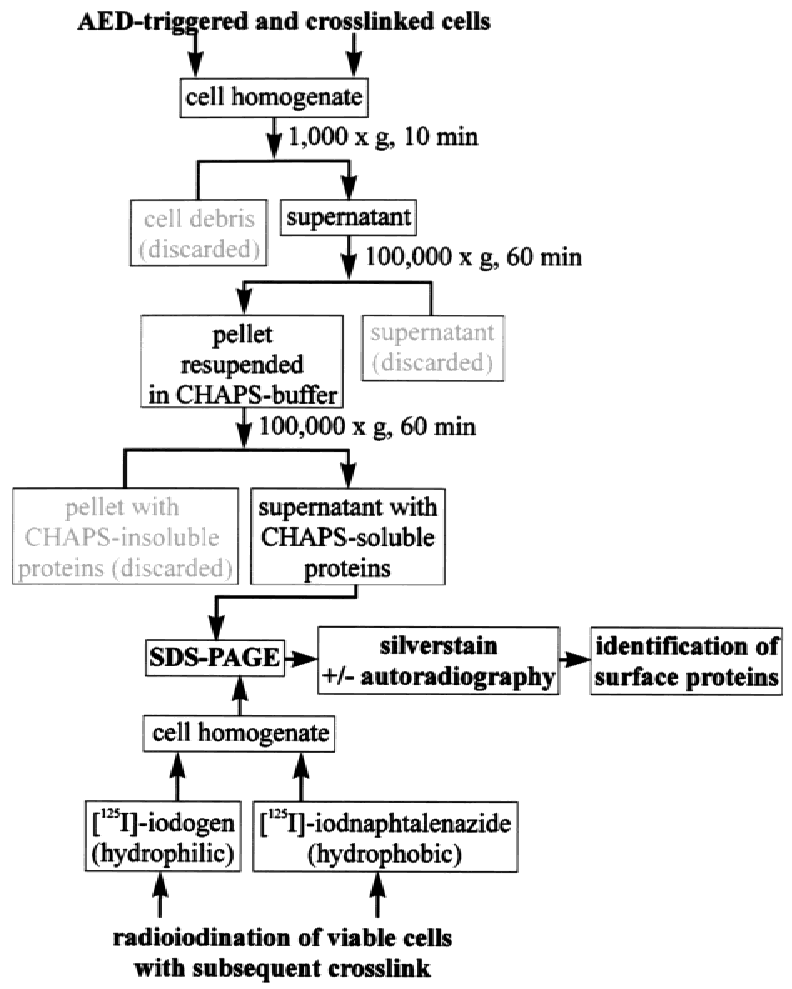

Fig. 1. Survey of different radio-labeling procedures and isolation of cell membrane proteins, with differential centrifugation and CHAPS extraction.

\section{GEL ELECTROPHORESIS}

Sodium dodecylsulfate polyacrylamide gel electrophoresis (SDSPAGE) was performed with a Laemmli-type system. After brief boiling in sample buffer ( $0.4 \mathrm{M}$ Tris-HCl, $0.035 \mathrm{M}$ SDS, $80 \mu \mathrm{M}$ EDTA, 1 $\mathrm{mg}$ bromphenolblue, $\mathrm{pH}$ 8.0) with or without preceding reduction of disulfidebonds by $0.5 \%$ dithiothreitol (DTT) samples were alcylated for $30 \mathrm{~min}$ in the dark with $2 \%$ iodacetamide. Most samples were analyzed on linear gradient (5 to $15 \%$ ) SDS-PAGE gels, with a $4 \%$ stacking gel, while 7.5 to $15 \%$ gels were used for cell membrane vesicles. Gels were stained with silver. Markers varied between 14.5 and $94 \mathrm{kDa}$ or 97 and $584 \mathrm{kDa}$, in low or high MW kits.

\section{Cell Surface Labeling by Hydrophilic \\ RADio-IODINATION IN Vivo Followed BY CROSSLINKING}

$5 \times 10^{4}$ cells in $5 \mathrm{ml}$ Pipes buffer $(5 \mathrm{~mm}$ Pipes, $1 \mathrm{~mm} \mathrm{KCl}, 1 \mathrm{~mm} \mathrm{CaCl}$, $\mathrm{pH}$ 7.0) were transferred into propylene vials coated with iodogen according to the manufacturers advice. Iodination, as outlined in Fig. 2 , was started by adding $500 \mu \mathrm{Ci}\left(1.8 \times 10^{7} \mathrm{~Bq}\right)$ of carrier-free $\mathrm{Na}\left[{ }^{125} \mathrm{I}\right]$, specific activity $=100 \mathrm{mCi} / \mathrm{ml}\left(3.6 \times 10^{9} \mathrm{~Bq} / \mathrm{ml}\right)$. After 15 min at $22^{\circ} \mathrm{C}$, cells were removed, washed 6-times with Pipes buffer, homogenized, and subjected to SDS-PAGE and ARG using Reflection ${ }^{(1 \times}$ ARG film (NEN, Köln, Germany). Crosslinking of the iodinated and washed cells was started by adding EGS or DFDNB, each in a final 


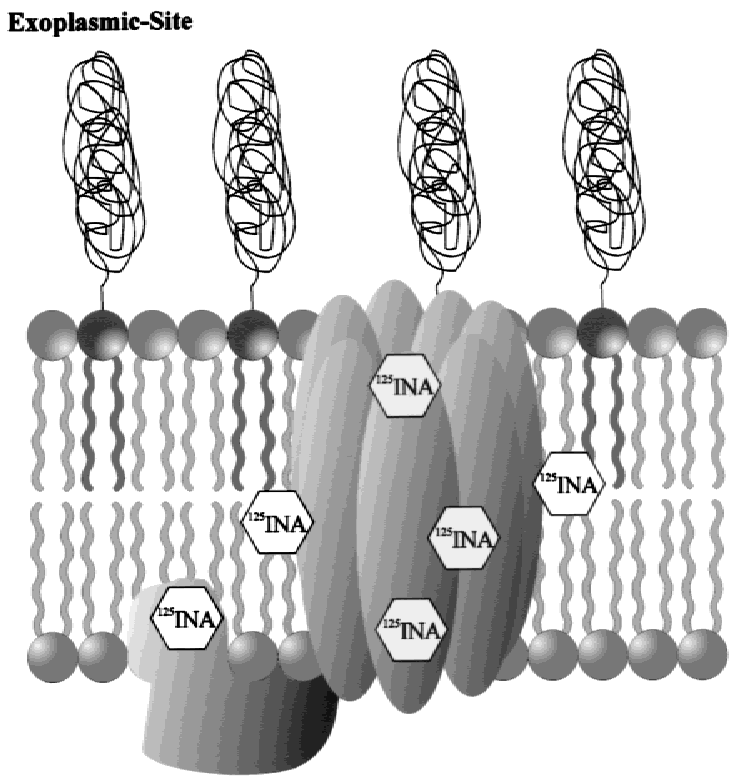

Cytoplasmic-Site<smiles></smiles>

5-[25] Iodonaphthyl-1-azide

5-[25]]Iodonaphthyl-1-nitrene

Hydrophobic-Labeling
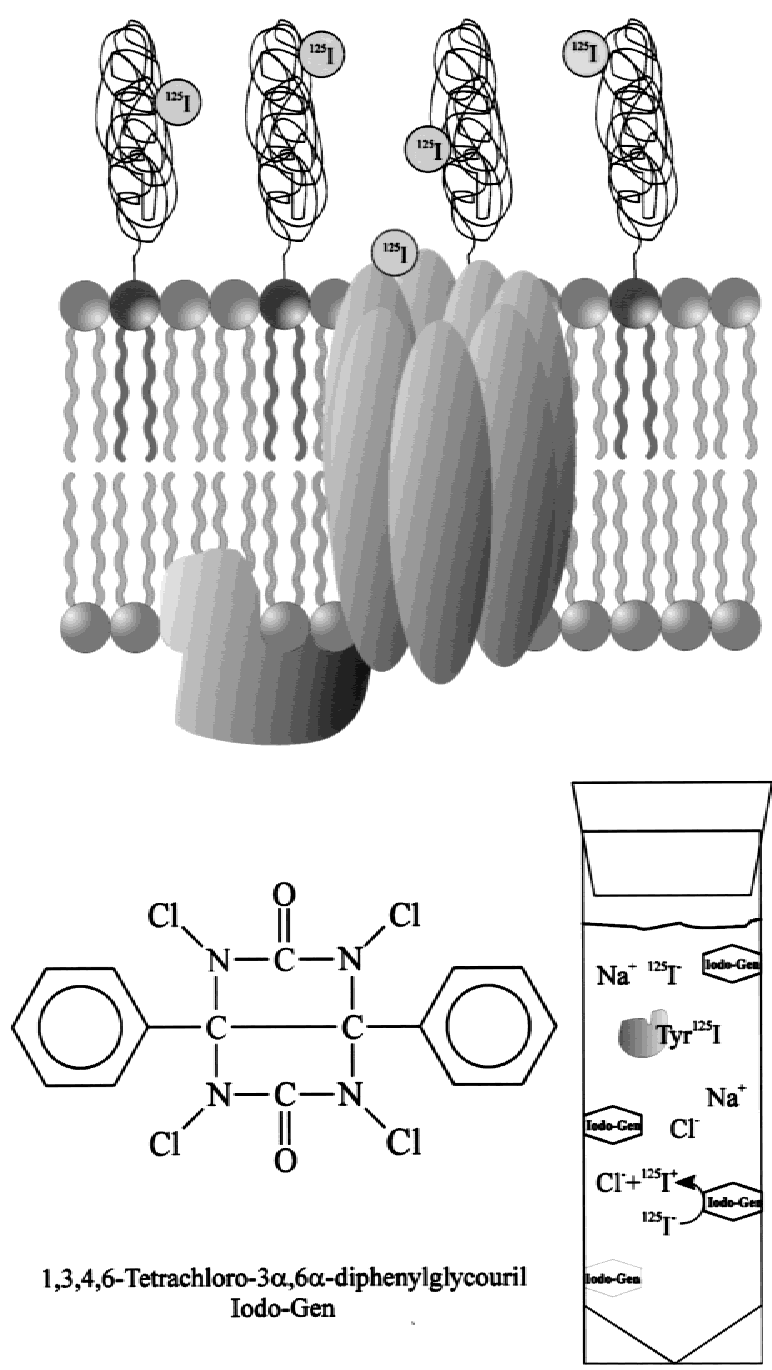

Hydrophilic-Labeling

Fig. 2. Principles and targets of the two different radio-iodination procedures used.

concentration of $0.2 \mathrm{mM}$. Crosslinkers were initially dissolved in DMSO (final concentration $<1 \%$ ). After $30 \mathrm{~min}$ incubation at $4{ }^{\circ} \mathrm{C}$ the reaction was quenched by adding cystein to a final concentration of 50 $\mathrm{mm}$ for further incubation, $30 \mathrm{~min}$ at $4{ }^{\circ} \mathrm{C}$. After crosslinking cells were treated as described below for noncrosslinked aliquots.

\section{Cell Surface Labeling by Lipophilic RADIO-IODINATION IN VIVO WITH SimultaneOUS CROSSLINKING}

$\left[{ }^{125} \mathrm{I}\right]$-INA was synthesized from 5-aminonaphthyl-1-azide and $\mathrm{Na}\left[{ }^{125} \mathrm{I}\right]$ according to "method 3" indicated by Bercovici and Gitler [5]. Purified $\left[{ }^{125} \mathrm{I}\right]$-INA was dissolved in ethanol, stored in the dark at $-20^{\circ} \mathrm{C}$, and used within 4 days after synthesis. $\sim 10^{4}$ cells in Dryl's solution (see above) were transferred into $1.5 \mathrm{ml}$ reaction vials and incubated for $1 \mathrm{~min}$ at $25^{\circ} \mathrm{C}$ under dimmed light $(\lambda \geq 600 \mathrm{~nm})$ with 500 $\mu \mathrm{Ci}\left(1.8 \times 10^{7} \mathrm{~Bq}\right)\left[{ }^{125} \mathrm{I}\right]-\mathrm{INA}$ per probe (specific activity $150 \mu \mathrm{Ci} / \mathrm{ml}$ $\left[0.55 \times 10^{7} \mathrm{~Bq}\right]$, final ethanol concentration $<1 \%$ ). For labeling, as outlined in Fig. 2, reaction vials were irradiated with a $150 \mathrm{~W}$ mercury lamp for $20 \mathrm{sec}$ at a distance of $10 \mathrm{~cm}$. Photoactivated crosslinking with HSAB was carried out by simultaneously incubating living cells with $\left[{ }^{125} \mathrm{I}\right]$-INA and $0.2 \mathrm{~mm} \mathrm{HSAB}$, which has been first dissolved in DMSO (final concentration of DMSO $<1 \%$ ). After labeling all further steps were made on ice. Cells were incubated for 15 min with Dryl's solution containing $0.1 \%$ BSA and washed three times with the same solution and two times, without BSA added. After labeling the cells were transferred in HM-Buffer containing the protease-inhibitor cocktail described below. They were then homogenized with 70 strokes in a glass-homogenizer with teflon-pestle (Braun, Melsungen, Germany). Cell debris were removed by brief centrifugation $(1,000 \times g, 10 \mathrm{~min})$ and the supernatants were subjected to SDS-PAGE and ARG (see above). The protease inhibitor cocktail used consisted of $3 \mu \mathrm{g} / \mathrm{ml}$ Aprotinin, $10 \mu \mathrm{M}$ E64, $100 \mu \mathrm{M}$ Leupeptin, $0.6 \mathrm{~mm}$ Pefabloc SC, $1 \mu \mathrm{M}$ Pepstatin A, $0.3 \mathrm{~mm}$ TAME. 
Preparation of Chaps-Soluble Membrane Proteins

See survey in Fig. 1. Cells ( 4 liters) were harvested and washed in Pipes buffer pH 7.3 (5 mM Pipes, $1 \mathrm{~mm} \mathrm{KCl,} 1 \mathrm{~mm} \mathrm{CaCl}_{2}$ ) at $22^{\circ} \mathrm{C}$. With some aliquots exocytosis was triggered by mixing cells with an equal volume of Pipes buffer containing $0.01 \%$ aminoethyldextran (AED). For details see Plattner et al. [33]. Cells were transferred into a mixture of $30 \mathrm{ml}$ deciliation buffer, $\mathrm{pH} 7.5$ ("STEN," containing 500 mu sucrose, $20 \mathrm{~mm}$ Tris, $4 \mathrm{~mm}$ EDTA, $6 \mathrm{~mm} \mathrm{NaCl}$ ) and $20 \mathrm{ml}$ Pipes buffer. Cells were then slowly cooled to $4^{\circ} \mathrm{C}$ with $0.4^{\circ} \mathrm{C} / \mathrm{min}$ to avoid exocytosis due to harsh temperature shift in control cells. Then $2 \mathrm{ml}$ of a $1 \mathrm{M} \mathrm{CaCl}_{2}$ solution was added to start deciliation (final $\mathrm{Ca}^{2+}$ concentration $\sim 40 \mathrm{~mm}$ ). When $95 \%$ of the cells were deciliated under lightmicroscope control, they were transferred into fresh STEN $\left(4^{\circ} \mathrm{C}\right)$ without EGTA but with $1 \mathrm{mM} \mathrm{CaCl}_{2}$. Crosslinking was then carried out by adding the crosslinkers dissolved in DMSO (final concentration $<1 \%$ ). After $30 \mathrm{~min}$ at $4^{\circ} \mathrm{C}$ the reaction was quenched by adding $50 \mathrm{~mm}$ cystein for $30 \mathrm{~min}$. Cells were then transferred, with two wash steps, into homogenization-buffer (HM-buffer) with protease inhibitors at $4^{\circ} \mathrm{C}$. The HM-buffer contained $250 \mathrm{~mm}$ sucrose, $20 \mathrm{~mm}$ Tris-maleate and $20 \mathrm{~mm} \mathrm{NaOH}, \mathrm{pH}$ 7.0. Homogenization of the cells was carried out by 100 strokes in a glass-homogenizer with a Teflon-pestle. From resulting crude extracts cell debris was removed by brief centrifugation $(10 \mathrm{~min}, 1,000 \times g)$. Supernatants were subjected to a $100,000 \times g$ centrifugation for $60 \mathrm{~min}$ at $4^{\circ} \mathrm{C}$. Resulting pellets were resuspended in $2 \mathrm{ml}$ of $50 \mathrm{~mm}$ bis-Tris, $5 \mathrm{~mm}$ CHAPS and $600 \mathrm{~mm} \varepsilon$-aminocapronic acid, $\mathrm{pH}$ 7.0. To obtain dissolved membrane proteins, suspensions were spun once again with $100,000 \times g$ for $60 \mathrm{~min}$ at $4^{\circ} \mathrm{C}$ and the resulting supernatants were subjected to SDS-PAGE.

\section{Isolation of Cell Membrane Vesicles by Two-Phase Aqueous Polymer Separation}

The method of Smith and Hennessey [44] was applied. Briefly, deciliated cells (see above) were homogenized in the presence of protease inhibitors (see above) to obtain a crude microsome suspension of intracellular and cell surface membranes. Preparations were done at $4^{\circ} \mathrm{C}$. Microsomes were first suspended in a mixture of two immiscible polymers, polyethyleneglycol P-3640 and dextran T500. During phase separation of the two polymers, right side-out cell membrane vesicles, due to their surface properties, partition exclusively into the upper phase which was removed by centrifugation, $10 \mathrm{~min}, 1,000 \times \mathrm{g}$. Finally, cell membrane vesicles were collected by centrifugation, $60 \mathrm{~min}$, $100,000 \times g$.

\section{Results}

Experiments presented were repeated at least twice, eventually up to four times.

\section{EXtracted Surface Antigens}

Surface antigens, largely representing high MW i-AGs, have been isolated from living cells by ethanolic extraction according to established methods $[10,23,38]$. On SDS-PAGE (Fig. 3, lane 1, -DTT) the main set of proteins migrates as two bands, 382 and $335 \mathrm{kDa}$, with two additional minor bands of 28 and $24 \mathrm{kDa}$. The two large main protein bands show a significant MW shift under reducing conditions (Fig. 3, lane 2, +DTT). In fact, an-
$\mathrm{kDa}$

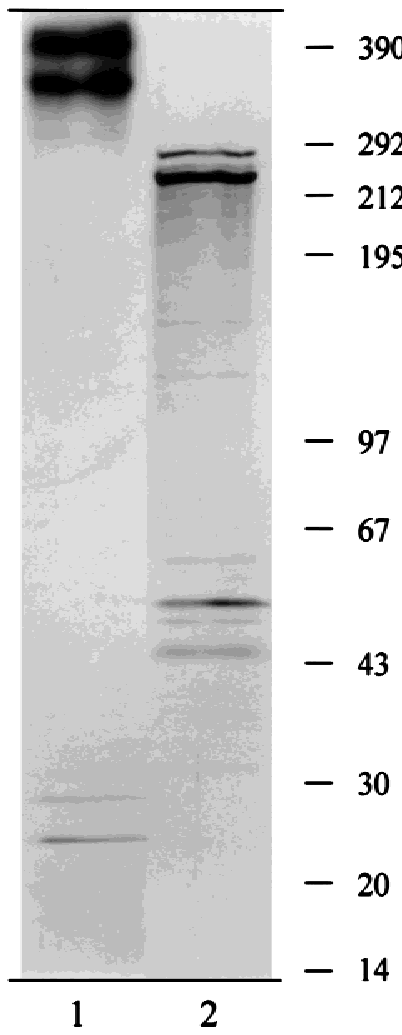

Fig. 3. Silver stained SDS-PAGE gel from ethanol extracted GPIanchored surface proteins, nonreducing (lane 1) or reducing conditions (lane 2), 3 min DTT. Iodacetamide $(2 \%)$ treatment for $30 \mathrm{~min}$ at $22^{\circ} \mathrm{C}$. Note shift of high MW bands and occurrence of additional mediumsized MWs in lane 2. Horizontal line on top marks start of separation gel.

tibodies prepared against these bands recognize just these bands on Western blots and in immuno-EM analysis they intensely label the glycocalyx [19]. This is not inhibited by the protease inhibitor cocktail used (see Materials and Methods and below) and, hence, may indicate inherent proteolytic activity, possibly activated by DTT (see below). On the gel DTT then allows fragmentation to become manifest due to reduction of the abundant disulfide bonds and the release of fragments thus produced. How to explain the double high MW bands in Figs. 3 and 4 (-DTT)? Although individual Paramecium cells can express only one serotype at a time, two different ones may be expressed in a population when cells shift from one serotype to another.

\section{Hydrophilic Labeling of the Cell Surface}

We then labeled living cells with $\left[{ }^{125} \mathrm{I}\right]$-iodogen. As Fig. 4 shows, elecrophoretic pattern $( \pm \mathrm{DTT})$ of labeled proteins is almost identical as with isolated surface antigens (shown in Fig. 3), with the exception that, under nonre- 


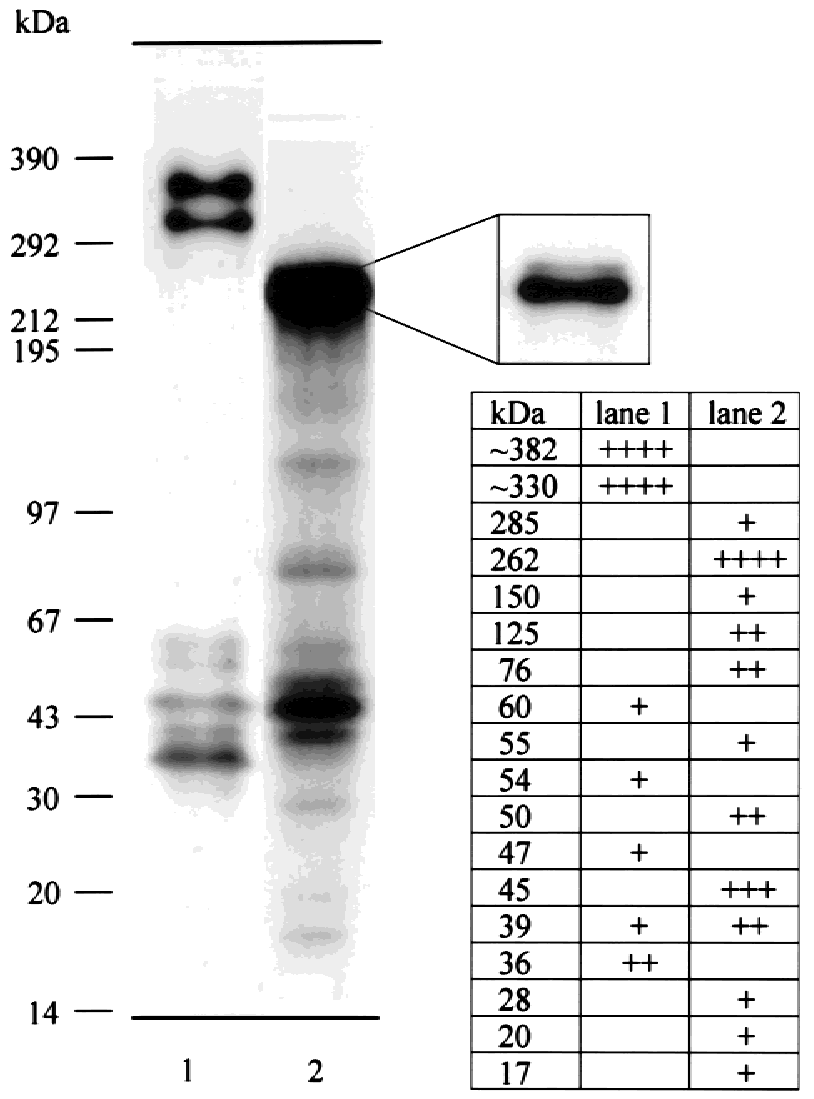

Fig. 4. Autoradiography of SDS-PAGE from cell homogenates (+ protease inhibitors) showing electrophoretic pattern of surface proteins labeled in vivo with $\left[{ }^{125} \mathrm{I}\right]$-iodogen. Nonreducing (lane 1) or reducing conditions (lane 2), 3 min DTT. Iodacetamide (2\%) treatment for 30 $\min$ at $22^{\circ} \mathrm{C}$. In lane 2 the $285 \mathrm{kDa}$ close to the $262 \mathrm{kDa}$ band is visible only after brief exposure (inset). Note that labeled bands comprise light MW forms (lane 1 and 2), as in Fig. 3, and some additional mediumsized bands (lane 2). Horizontal line on top marks start of separation gel.

ducing conditions (Fig. 4, lane 1), an additional set of proteins of $60,54,47,39$, and $36 \mathrm{kDa}$ appears. Under reducing conditions (Fig. 4, lane 2) a strong $262 \mathrm{kDa}$ band preodominates over a weak $285 \mathrm{kDa}$ band which becomes visible only after short exposure (Fig. 4, inset). It has to be noted that so far, similarities can be discussed only on the basis of MW. The major extracted surface proteins seen after silver staining (Fig. 3) are also radioiodinated. In Fig. 4 (lane 2), under reducing conditions, lower MW bands appear slightly smaller than under nonreducing conditions, perhaps due to $\mathrm{S}$-S unfolding. Though such small differences are difficult to ascertain, the $60 \mathrm{kDa}$ band may correspond to the $55 \mathrm{kDa}$ band, 54 $\mathrm{kDa}$ to $50 \mathrm{kDa}$, and $47 \mathrm{kDa}$ to $45 \mathrm{kDa}$, while the $39 \mathrm{kDa}$ band is unaltered. The $36 \mathrm{kDa}$ band (-DTT) may fragment into 28, 20 and $17 \mathrm{kDa}$ (+DTT). Two bands of 28 and $24 \mathrm{kDa}$ appear under nonreducing conditions in the isolated surface proteins (Fig. 3), while they are not amenable to radio-iodination (Fig. 4, lane 1).
Proteolytic Activity in the Extracts of SuRface Antigens and Their Potential Contribution to SDS-PAGE GEL BAND DiVERSITY

As it is well known that cystein proteases can be activated by thiols like DTT and inhibited by alkylation with iodacetamide, we checked the possible existence of a copurified cystein protease in the ethanolic extracts of i-AG fractions by different treatments of this fraction before the regular SDS-PAGE. While in Fig. 5, lane 1 shows the well known picture of an $\mathrm{i}-\mathrm{AG}$ fraction in Ag-stained SDS-PAGE, lane 2 was obtained after $1 \mathrm{hr}$ DTT treatment, showing the almost total degradation of the i-AGs. Lane 3 shows the inhibition of this effect by preceding incubation with iodacetamide. Can these results be attributed to a co-isolated protease? To address this question, we repeated the experiments with BSA added to the i-AG fraction. This foreign protein is also degraded by the putative protease contained in the ethanolic extract (Fig. 5, lane 5), under conditions comparable to lane 2 ( $1 \mathrm{hr}$ DTT), while in lane 4 this is inhibited by sample boiling before $1 \mathrm{hr}$ DTT treatment. In this case, BSA is still visible as an intense band of $66 \mathrm{kDa}$ (Fig. 5, arrowhead). Therefore, we infer cleavage of large MW surface components by an endogenous coextractable protease which is activated by DTT. Remarkably this may occur within a short time, e.g., during sample preparation for SDS-PAGE, but it is inhibited by alkylation (Fig. 5, lane 3), by boiling (Fig. 5, lane 4), or by adding a specific cystein protease inhibitor E64 (data not shown). Lower MW bands are not affected (Fig. 5). The $33 \mathrm{kDa}$ band may represent a cathepsin L like protease released in large amounts to the medium [51] which may be responsible for the large MW shift we see and which may undergo self-digestion in lanes 2 and 5 of Fig. 5.

From these data we conclude that endogenous protease activity can affect protein bands and that this must be counteracted by alkylation with iodacetamide before applying DTT for SDS-PAGE.

\section{Lipophilic Labeling of Cell Membrane Components}

Next we tried to see which proteins can be labeled in vivo by lipophilic $\left[{ }^{125} \mathrm{I}\right]$-INA (Fig. 6, +DTT). Labeling requires UV irradiation (lane 1) which was combined with the photolabile crosslinking agent, HSAB (lane 2). Cells survive when manipulations are restricted, e.g., to $20 \mathrm{sec}$. As lane 1 shows, without crosslinking, large MW proteins remain completely unlabeled, labeling being restricted to sizes of $\leq 122 \mathrm{kDa}$. Under nonreducing conditions, the electrophoretic pattern was the same (data not shown). Closer inspection reveals similarities to iodogen-labeled samples (+DTT), as summarized in the Table. These proteins of 55, 50,45, 39, $20 \mathrm{kDa}$, therefore, cannot be derived from i-AGs. Some iodogen 


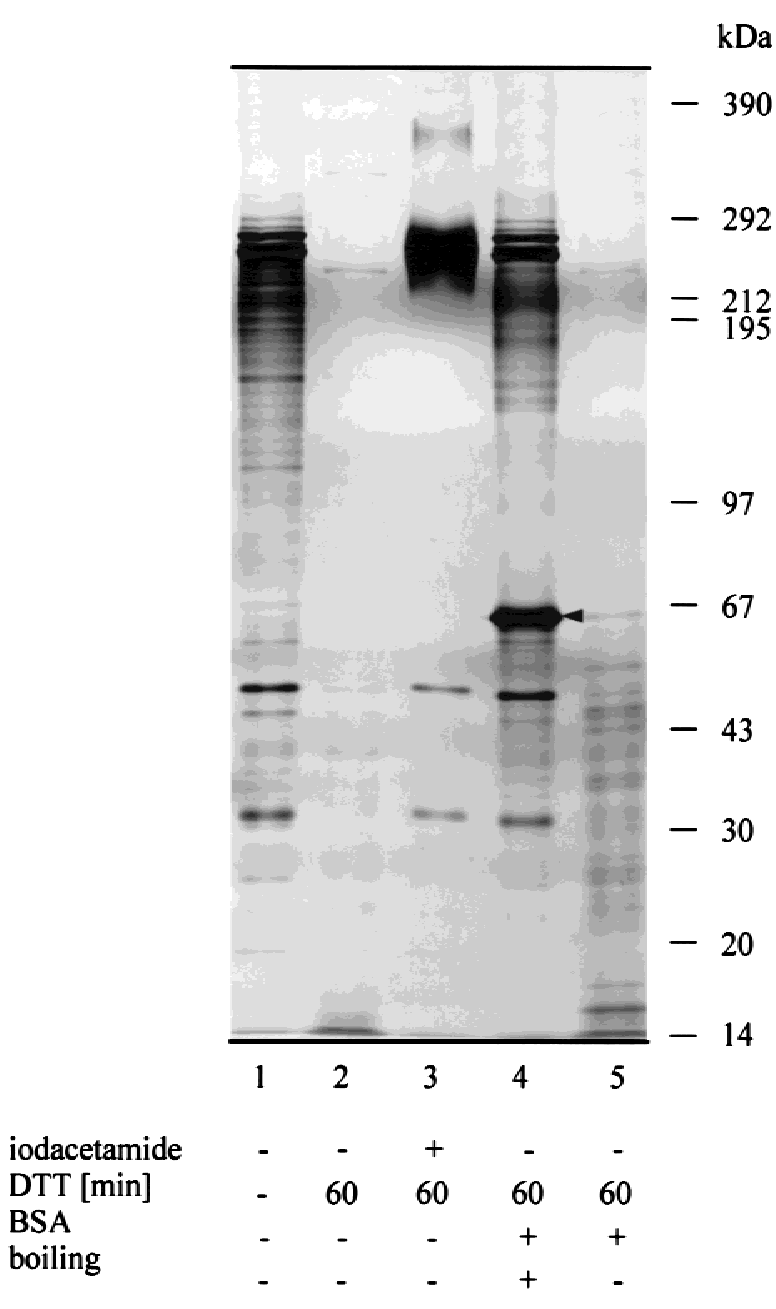

Fig. 5. Silver stained SDS-PAGE of ethanol extracted GPI-anchored surface protein fraction. Evidence of proteolytic activity and disulfide bond dissociation caused by prolongated DTT treatment and its avoidance by iodacetamide or boiling. Top horizontal line marks start of separation gel. Fragmentation may be caused by inherent protease activation by DTT (see Discussion) depending on time of DTT $(0.5 \%)$ treatment (lane 1, $3 \mathrm{~min}$, lanes 2-5, $60 \mathrm{~min}$ ). Addition of iodacetamide (2\%) before DTT inhibits, though not completely, dissociation of fragments from high MW proteins (lane 3). Fragmentation cannot be avoided by boiling since high MW forms of $\geq 100 \mathrm{kDa}$ are seen in lane 4 , in addition to the $\geq 250 \mathrm{kDa}$ forms. BSA ( $1 \mu \mathrm{g}$ per lane, arrowhead $)$ has been added to differentiate between proteolysis (lane 5) and S-S linkage fragmentation (lane 4).

labeled bands obtained under nonreducing or reducing conditions, respectively, are only slightly diverging, e.g., $60 v s .55 \mathrm{kDa}, 54$ vs. 50 , or 47 vs. $45 \mathrm{kDa}$. However, we did not analyze in any detail whether the smaller size obtained with DTT is due to reduction or to proteolytic effects. Four bands of 122, 104, 94, and $26 \mathrm{kDa}$ are exclusively labeled by $\left[{ }^{125} \mathrm{I}\right]-\mathrm{INA}$, and, hence, may be integral or internal membrane associated proteins. When the cells are simultaneously crosslinked (lane 2), changes in three protein bands occur, i.e., a band of $104 \mathrm{kDa}$ disappears and two bands of 145 and $270 \mathrm{kDa}$ are formed anew. For potential interpretations, see Discussion.

\section{Hydrophilic Labeling of Cell Surface Components AND SubSEQuent CROSSLINKING}

In Fig. 7 we present samples (+ protease inhibitors) labeled by $\left[{ }^{125} \mathrm{I}\right]$-iodogen, with or without crosslinking, either by EGS or DFDNB, respectively. The noncrosslinked control is contained in Fig. 2. Both crosslinkers are not easily applicable in vivo and both, particularly EGS, produce very high MW forms (gel 1). Surprisingly, these large MW products can be split by DTT, especially after DFDNB (gel 2). This may be explained as follows. The more extended EGS spacer may crosslink S-S linked chains, which then can be dissociated by DTT, although not to the size of the much smaller bands which we normally see with DTT without crosslinking (see above). Other bands appear less affected, e.g., those of 39, 45 or $55 \mathrm{kDa}$. A new band of 81 $\mathrm{kDa}$ is prominent after both crosslinkers (+DTT) in Fig. 7 (gel 2, lanes 1 and 2). Moreover, EGS produces DTTresistant bands of 369 and $>510 \mathrm{kDa}$ (Fig. 7, gel 2, lane 1). For a tentative interpretation, see Discussion.

\section{CHAPS Solubilization of Membrane Proteins}

CHAPS is known to extract integral membrane proteins $[22,43]$. Figure 8 demonstrates extraction of a wide range of proteins from Paramecium cells. We compare normal cells with aliquots after massive exocytosis stimulation by AED, since this is known to be accompanied by dispersal of some oligomeric cell membrane proteins (see Discussion). For comparison aliquots were also crosslinked by DFDNB after triggering. Numerical data achieved are contained in Fig. 8, and include a change of a variety of bands in the course of exocytosis stimulation. Without crosslinking bands of 285, 73, 61, $40,38,24$, and $16 \mathrm{kDa}$ disappear, while bands of 131 , 102,100 , and $95 \mathrm{kDa}$ reappear. With crosslinking, after AED stimulation, we observe occurrence of 121 and 102 bands, while $285,141,90,70,42,39,24,18$, and $15 \mathrm{kDa}$ bands are seen only in nonstimulated cells. For interpretation, see below.

\section{Isolated Cell Membrane Vesicles}

Another method to get access to cell membrane proteins is presented in Fig. 9 which shows an SDS-PAGE profile after isolation by phase separation. This fraction is selective for GPI-anchored surface proteins while those occurring in a variety of intracellular compartments [19] are not "seen" by this method. As seen in the Table, all of the bands seen after ethanolic or CHAPS extraction or after radio-iodination by either of the two methods ap- 


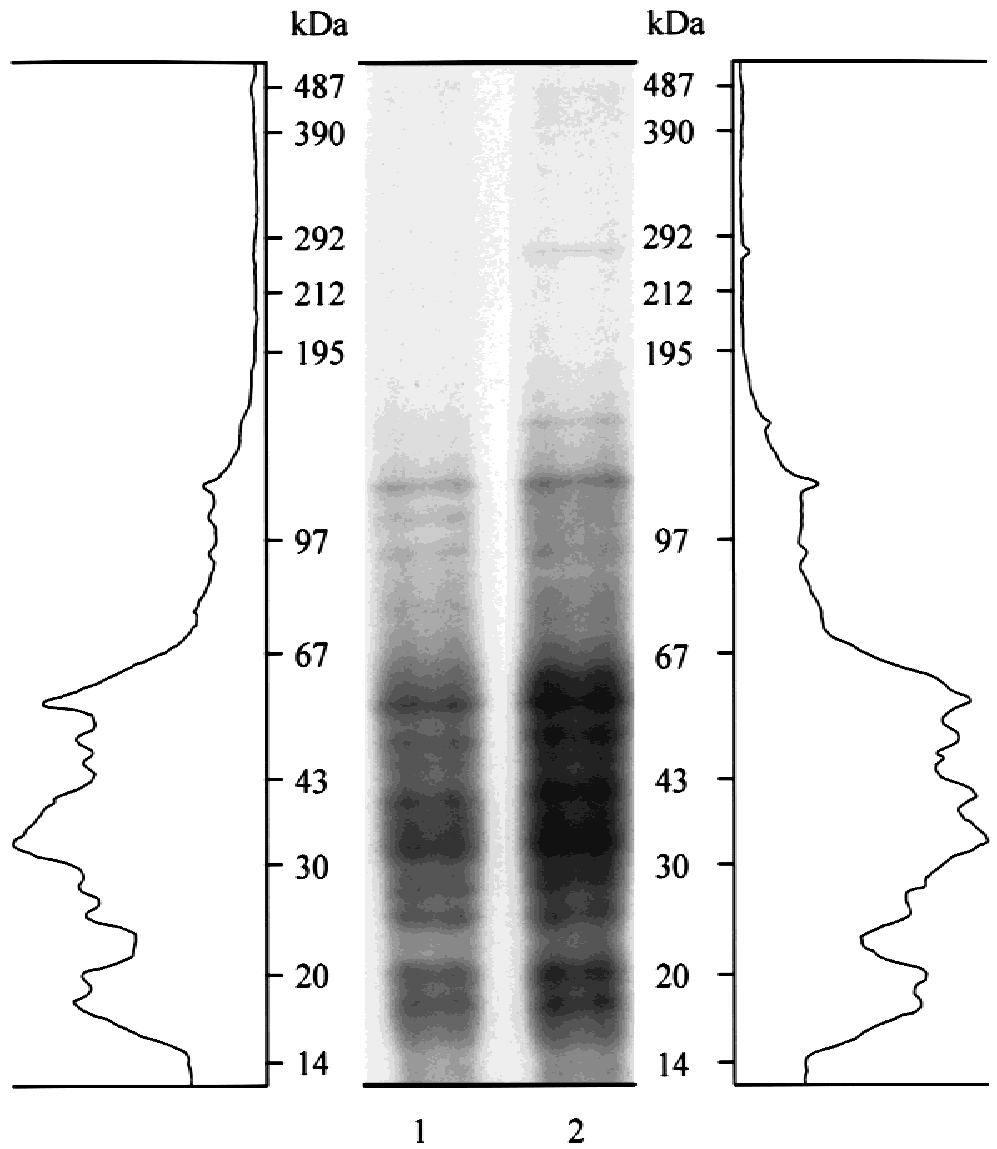

\begin{tabular}{|l|c|c|}
\hline $\mathrm{kDa}$ & lane 1 & lane 2 \\
\hline 270 & & + \\
\hline 145 & & ++ \\
\hline 122 & + & ++ \\
\hline 104 & + & \\
\hline 94 & ++ & ++ \\
\hline 55 & ++ & +++ \\
\hline 50 & ++ & ++ \\
\hline 45 & + & + \\
\hline 39 & ++ & ++ \\
\hline 32 & ++ & ++ \\
\hline 26 & ++ & ++ \\
\hline 24 & ++ & ++ \\
\hline 20 & ++ & ++ \\
\hline 17 & ++ & ++ \\
\hline
\end{tabular}

Fig. 6. SDS-PAGE autoradiography of homogenates (+ protease inhbitors) obtained by in vivo labeling with $\left[{ }^{125} \mathrm{I}\right]-\mathrm{INA}$. Lane 1 , without crosslinker, lane 2, with $0.2 \mathrm{~mm}$ HSAB. Note absence of labeling in high MW regions and MW shift of some bands, as evidenced by densitometer scans.

plied are contained in the isolated cell membrane fraction.

\section{Discussion}

Our goal was to obtain more insight into molecular constituents of Paramecium cells beyond the overwhelming content of GPI-anchored proteins. The only method available to isolate cell membranes is based on such components [44] and, therefore, must be highly selective. On the other hand, such components are distributed intracellularly over vast compartments [19] and they are liable to degradation during isolation, thus yielding false signals (this paper). Therefore, we developed a combination of new approaches.

Using SDS-PAGE we have first isolated i-AG fractions (Fig. 3) which we then compared with bands obtained by hydrophilic (Fig. 4) or lipophilic (Fig. 6) radioiodination. Additionally, we controlled degradation of i-AGs which are most sensitive to DTT-activated endogenous proteases (Fig. 5). On this basis, combined with crosslinking experiments, we can obtain more reliable information on "genuine" cell membrane proteins in our system. As to the other dominant protein type, we can exclude any significant contamination of our fractions by the most abundant secretory proteins of dense-core vesicles, the "trichocysts," because of their small size and dimer $\leftrightarrow$ monomer transition with DTT [47] which we do not see.

\section{Proteolytic EFFECTS}

When unaffected by proteolytic effects, i-AG bands are of 380 and $330 \mathrm{kDa}$ under nonreducing, and of 285 and $262 \mathrm{kDa}$ under reducing conditions, respectively. Minor bands, including a fairly constant $45 \mathrm{kDa}$ band, are also included, as reported previously [1]. Time-dependency of DTT effects clearly indicates proteolysis which cannot easily be counteracted by usual protease inhibitors [10], superimposed by disulfide bond cleavage [21]. The thiol-activated protease originally envisaged by Hansma [21] can possibly be attributed to cathepsin L, a $33 \mathrm{kDa}$ secretory product found in spent Paramecium culture 
Table. Survey of electrophoretic patterns derived from Figs. 3, 4 and $6 *$ showing that lipophilic $\left[{ }^{125}\right.$ I]-INA labels medium-sized proteins different from those "seen" by hydrophilic [ $\left.{ }^{125} \mathrm{I}\right]$-iodogen which largely comprise i-AGs.

\begin{tabular}{|c|c|c|c|c|c|c|}
\hline $\begin{array}{c}\text { Molecular } \\
\text { mass } \\
{[\mathrm{kDa}]}\end{array}$ & $\begin{array}{l}\text { Extract } \\
\text { anchore } \\
\text { prot }\end{array}$ & $\begin{array}{l}\text { d GPI- } \\
\text { surface } \\
\text { eins }\end{array}$ & $\begin{array}{r}\text { In viv } \\
\text { labeling } \\
\text { protei } \\
\text { iod }\end{array}$ & $\begin{array}{l}\text { radio- } \\
\text { f surface } \\
\text { is with } \\
\text { gen }\end{array}$ & $\begin{array}{l}\text { In vivo radio- } \\
\text { labeling of } \\
\text { membrane } \\
\text { proteins with }\end{array}$ & $\begin{array}{l}\text { Proteins in } \\
\text { isolated plasma- } \\
\text { membrane } \\
\text { vesicles }\end{array}$ \\
\hline & $\begin{array}{l}\text { Non } \\
\text { reduced }\end{array}$ & Reduced & $\begin{array}{l}\text { Non } \\
\text { reduced }\end{array}$ & Reduced & $\begin{array}{c}\text { Non } \\
\text { reduced/reduced }\end{array}$ & Reduced \\
\hline-382 & ++++ & & ++++ & & & \\
\hline-330 & ++++ & & ++++ & & & \\
\hline 285 & & $\overline{+++}$ & & $+t$ & & ++++ \\
\hline 262 & & ++++ & & ++++ & & $+11+$ \\
\hline 150 & & + & & + & & +++ \\
\hline 125 & & + & & ++ & & ++ \\
\hline 122 & & & & & ++ & + \\
\hline 104 & & & & & + & ++ \\
\hline 93 & & & & & ++ & ++ \\
\hline 76 & & & & ++ & & ++ \\
\hline 63 & & + & & & & ++ \\
\hline 60 & & & F & & & + \\
\hline 55 & & ++ & & $2+$ & +++ & +++++ \\
\hline 54 & & & $+F_{3}$ & & & \\
\hline 52 & & + & & & & \\
\hline 50 & & & & ++ & $\overline{++}$ & ++++ \\
\hline 47 & & & + & & & \\
\hline 45 & & ++ & & $x+++$ & ++ & +++ \\
\hline 39 & & & F- & $\rightarrow++$ & ++ & ++ \\
\hline 36 & & & ++ & & & \\
\hline 32 & & + & & & ++ & ++ \\
\hline 28 & + & & & + & & + \\
\hline 26 & & & & & ++ & + \\
\hline 24 & + & & & 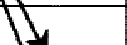 & ++ & + \\
\hline 20 & & & & + & ++ & ++ \\
\hline 17 & & & & + & ++ & ++1 \\
\hline
\end{tabular}

* Labeling intensities: ++++ very strong, +++ strong, ++ medium, + weak. Encased or light-gray marked crosses (+) point to identities of electrophoretic patterns. Dark-gray marked crosses $(+)$ indicate bands selectively labeled with the corresponding approach. Dotted outlines indicate a set of proteins, which undergoes, under nonreducing conditions, a shift to lower MW, probably dure to reduction by DTT (arrows).

Only those protein bands from isolated plasma-membrane vesicles are listed which also occur in any of the other preparations (additional bands indicated in Fig. 9). For further details, see text.

medium [51] which also occurs in Tetrahymena [48]. Concomitantly, in Fig. 5, we see a $33 \mathrm{kDa}$ band which apparently undergoes (auto-?)digestion with increasing DTT exposure time.

\section{SURFACE RADIO-IODINATION}

Standard methods work with hydrophilic agents like iodogen [40]. Yet in cells with extensive GPI-anchord i-
AGs these may practically be the only proteins labeled, as we realize (Fig. 4) and they may by far outnumber any other important components. In contrast, gels from cell membranes isolated from Paramecium cells contain a large spectrum of other proteins (Fig. 9). Most importantly, proteins of this type are widely different from fragmentation products of i-AGs (see above and Fig. 5). The medium- to small-sized membrane proteins labeled by $\left[{ }^{125} \mathrm{I}\right]$-INA cannot be considered as such degradation 


\section{gel $1 \quad$ gel 2}

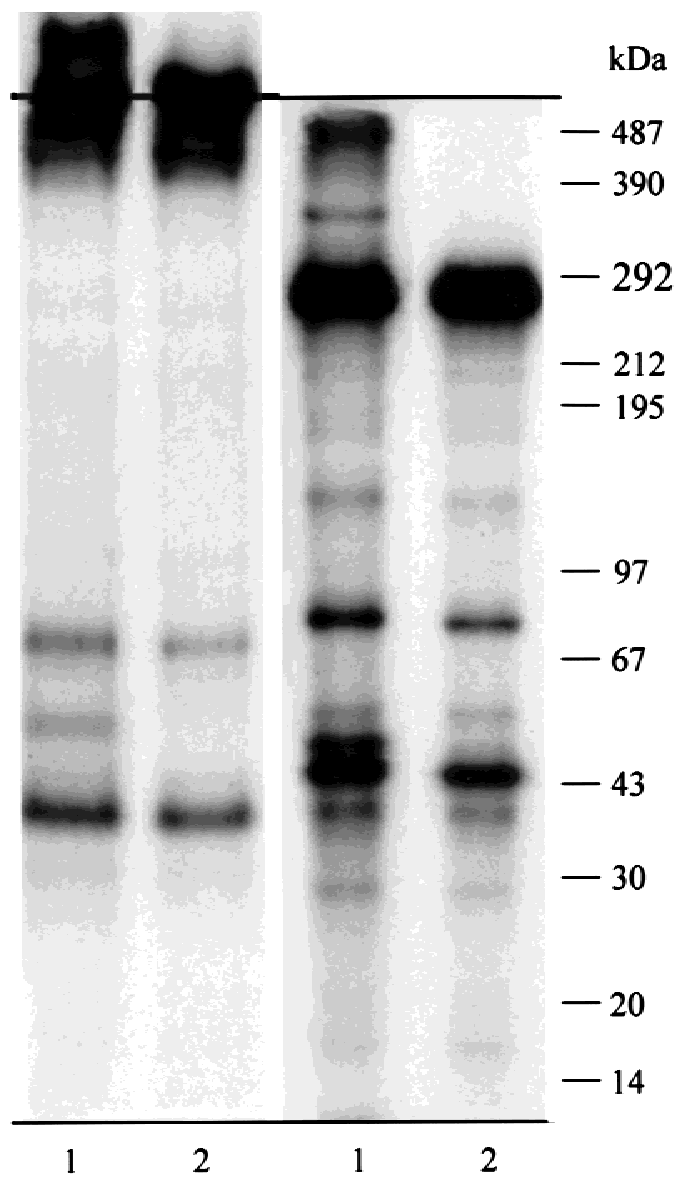

\begin{tabular}{|c|c|c|c|c|}
\hline & \multicolumn{2}{|c|}{ gel 1 } & \multicolumn{2}{c|}{ gel 2 } \\
\hline kDa & lane 1 & lane 2 & lane 1 & lane 2 \\
\hline$>510$ & +++ & ++ & +++ & \\
\hline$\sim 369$ & & & ++ & \\
\hline 262 & & & ++ & +++ \\
\hline 125 & & & ++ & + \\
\hline 81 & & & +++ & ++ \\
\hline 76 & ++ & + & & \\
\hline 55 & + & & ++ & + \\
\hline 50 & & & ++ & \\
\hline 45 & & & +++ & +++ \\
\hline 39 & ++ & +++ & +++ & ++ \\
\hline 28 & & & ++ & + \\
\hline 17 & & & + & + \\
\hline
\end{tabular}

Fig. 7. SDS-PAGE autoradiography of homogenates (+ protease inhibitors) obtained by in vivo labeling with $\left[{ }^{125} \mathrm{I}\right]$-iodogen, with or without subsequent crosslinking. Gel 1, lane 1, +EGS, -DTT. Gel 1, lane 2, +DFDNB, -DTT. Gel 2, lane 1, +EGS, +DTT. Gel 2, lane 2, +DFDNB, +DTT. Horizontal line on top marks start of separation gel. Note more pronounced MW size effect by the larger spacer, EGS $( \pm D T T)$. Noncrosslinked control is identical with Fig. 4.

products, but rather as genuine membrane components, because they are obtained by labeling live cells, because of their size range (see below), and because they remain unaltered with DTT (Fig. 6).

\section{Possible Molecular Equivalents}

By combining CHAPS extraction of integral proteins with exocytosis stimulation and/or crosslinking (an approach not possible with isolated cell membranes), we hoped to see some changes pertinent to cell membrane structure. As expected, several bands undergo changes (Fig. 8) and some bands coincide with $\left[{ }^{125}\right.$ I]-INA labeling. On this basis, we can speculate on a few potential candidates.

To our knowledge Schwaller et al. [42] were the only ones applying $\left[{ }^{125} \mathrm{I}\right]$-INA labeling to a secretory system, i.e., chromaffin cells. In depolarizationactivated cells, INA labeled several proteins, some of which were identified on Western blots as annexins. In Paramecium, we had identified binding sites for antibodies (ABs) against annexin-specific peptides, anti-call-15 $\mathrm{ABs}$ and anti-B-15-ABs [25]. The first labels trichocyst docking sites and the second labels another exocytosis site, the cytoproct, while on Western blots ABs tag bands of 44.5 to 46 and $51 \mathrm{kDa}$, respectively. This is compatible with bands labeled by INA (Fig. 6). Calmodulin is also associated with the cell membrane, including exocytosis sites. This has been shown by EM immunocytochemistry $[29,31,32]$ and it must be inferred from the presence of a calmodulin-binding domain in the plasmalemmal $\mathrm{Ca}^{2+}$-pump $[16,49]$. Considering variation between experiments and possible modifications, these aspects would be compatible with occurrence of 17 or 18 $\mathrm{kDa}$ and 121 to $145 \mathrm{kDa}$ bands (Figs. 6 and 8). 

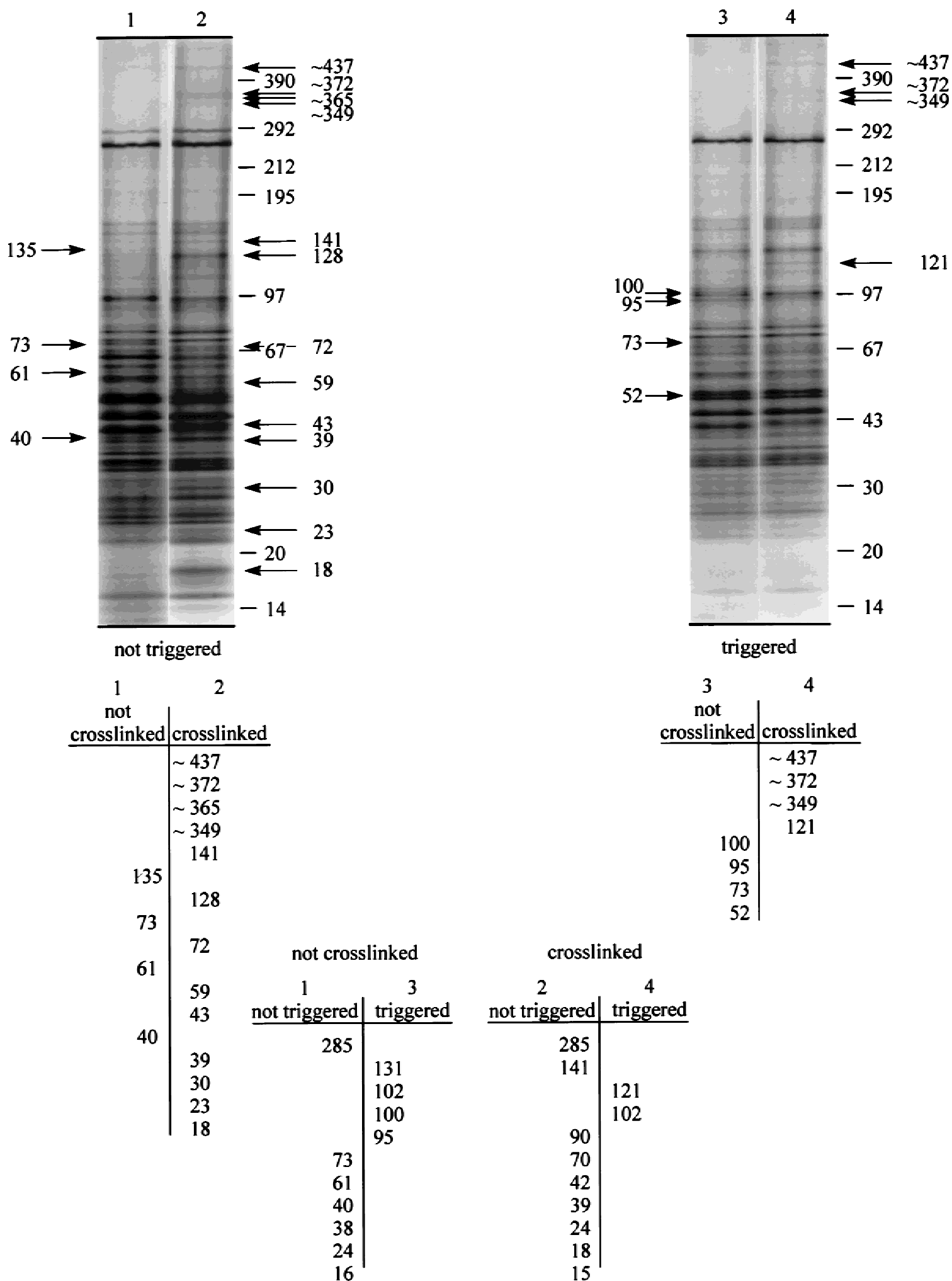

Fig. 8. Silver stained SDS-PAGE gel from CHAPS-solubilized membrane proteins. The electrophoretic patterns of membrane proteins (+DTT, +protease inhibitors) from triggered and nontriggered cells, with or without subsequent crosslinking, are compared. Numerical data refer to bands changed when (non-)crosslinked or (non-)triggered pairs are compared. "Triggered" means total exocytosis stimulation with $0.005 \%$ AED, "crosslinked" means exposure to $0.3 \mathrm{~mm}$ DFDNB $\left(30 \mathrm{~min}, 4^{\circ} \mathrm{C}\right)$, eventually after AED. 


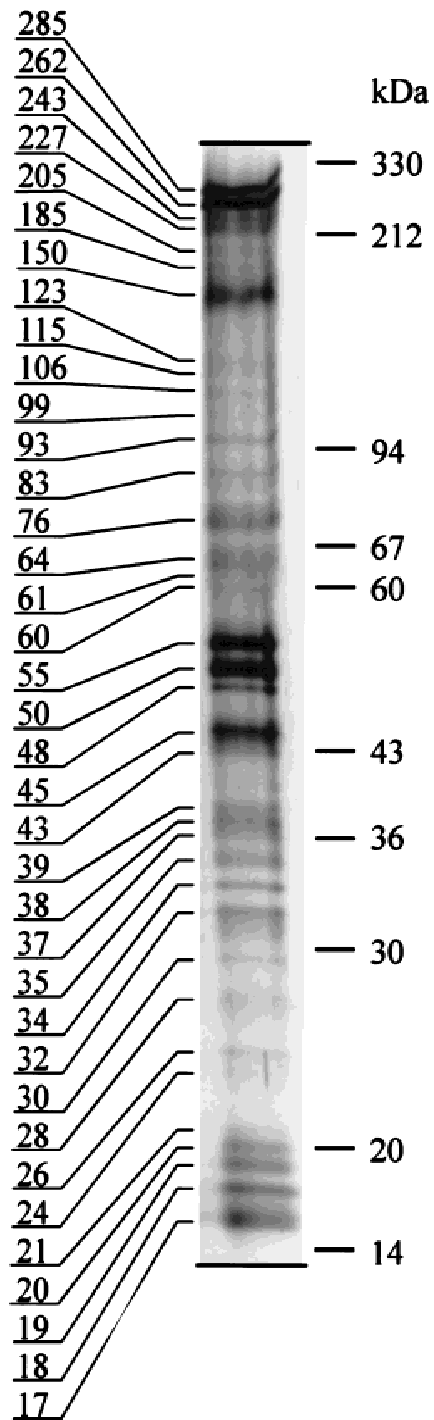

Fig. 9. Silver stained SDS-PAGE gel $(7.5$ to $15 \%,+D T T$, +protease inhibitors) obtained from isolated cell membrane vesicles.

Another aspect concerns preformed trichocyst exocytosis sites which, in Paramecium contain a group of 7 to 8 "rosette" particles [34] identified as integral proteins [50]. On high resolution $\mathrm{Ta} / \mathrm{W}$ replicas, one such particle measures, with the metal pile-up subtracted, $\sim 12 \mathrm{~nm}$ [35]. Assuming a density of 1.2, a global molecular mass of $\sim 650 \mathrm{kDa}$ would result [36]. Since every rosette particle decays into 6 subunits [26], this would yield $\sim 110 \mathrm{kDa}$ subunits. Unfortunately, products from their crosslinking within a rosette particle would no more be recognizable on our SDS-PAGE analysis. Assuming a $1.4 \mathrm{~nm}^{2}$ area occupied by one membrane-spanning helix in freeze-fracture replicas [17], every subunit of a rosette particle could then accommodate 10 transmembrane helices. This would also be compatible with one $\mathrm{Ca}^{2+}$ pump as a molecular equivalent, since it possesses 10 transmembrane domains in Paramecium [16] just as in other systems [30]. Slight deviation from actual MW values could be due to some modifications. Since this has not yet been analyzed in detail with our system, we can only emphasize the compatibility of our data with the few molecular data available.

\section{Conclusions}

Inhibition of DTT-activation of proteases can reduce medium-sized protein bands caused by i-AG decay. These may normally predominate in hydrophilic radioiodination experiments, whereas we show usefulness of in vivo lipophilic radio-iodination which results in totally different, medium-sized bands. These data are now amenable to detailed analysis in Paramecium and the method used may be successfully applied to related parasitic protozoa whose GPI-anchored surface variant antigens represent a major medical challenge $[15,20,28]$.

We thank Dr. Kurt Rosenheck (Weizmann Institute of Science, Rehovot, Israel) for introducing the INA-labeling method in our laboratory and Dr. J.-D. Wissmann for establishing this method in some preliminary experiments.

\section{References}

1. Adoutte, A., Ling, K.Y., Chang, S., Huang, F., Kung, C. 1983. Physiological and mutational protein variations in the ciliary membrane of Paramecium. Exp. Cell Res. 148:387-404

2. Azzouz, N., Striepen, B., Gerold, P., Capdeville, Y., Schwarz, R.T. 1995. Glycoinositol-phosphoceramide in the free-living protozoan Paramecium primaurelia: modification of core glycans by mannosyl phosphate. EMBO J. 14:4422-4433

3. Beale, G.H. 1952. Antigen variation in Paramecium aurelia, variety 1. Genetics 37:62-74

4. Beale G.H. 1954. Genetics of Paramecium aurelia. Cambridge University Press, Cambridge

5. Bercovici, T., Gitler, C. 1978. 5- ${ }^{125}$ I.Iodonaphthylazide, a reagent to determine the penetration of proteins into the liquid bilayer of biological membranes. Biochemistry 17:1484-1489

6. Bleyman, L.K. 1996. Ciliate genetics. In: Ciliates. Cells and Organisms. K. Hausmann and P.C. Bradbury, editors. pp. 291-324. Gustav Fischer-Verlag, Stuttgart, Jena

7. Bolivar, I. 1983. Immunological crossreactivity of Paramecium surface antigens: conformational differences account for cell surface specificity. Proc. Natl. Acad. Sci. USA 80:1003-1007

8. Capdeville, Y. 1971. Allelic modulation in Paramecium aurelia heterozygotes. Mol. Gen. Genet. 112:306-316

9. Capdeville, Y., Baltz, T., Derengnaucourt, C. Keller, A.-M. 1986. Immunological evidence of a common structure between Paramecium surface antigens and Trypanosoma variant surface glycoproteins. Exp. Cell Res. 167:75-86

10. Capdeville, Y., Benwakrim, A. 1996. The major ciliary membrane proteins in Paramecium primaurelia are glycosylphosphatidylinositol anchored proteins. Eur. J. Cell Biol. 70:339-346

11. Capdeville, Y., Cardoso de Almeida, M.L., Deregnaucourt, C. 1987a. The membrane-anchor of Parameciuim temperature- 
specific surface antigens is a glycosylinositol phospholipid. Biochem. Biophys. Res. Commun. 147:1219-1225

12. Capdeville, Y., Caron, F., Antony, C., Deregnaucourt, C., Keller, A.M. 1987b. Allelic antigen and membrane-anchor epitopes of Paramecium primaurelia surface antigens. J. Cell Sci. 88:553-562

13. Capdeville, Y., Charret, R., Antony, C., Delorme, J., Nahon, P., Adoutte, A. 1993. Ciliary and plasma membrane proteins in Paramecium: description, localization and intracellular transit. In: Membrane Traffic in Protozoa. H. Plattner, editor. pp. 181-226. JAI Press, Greenwich, CT, London

14. Deregnaucourt, C., Keller, A.M., Capdeville, Y. 1988. A new class of Paramecium surface proteins anchored in the plasma membrane by a glycosylinositol phospholipid. Membrane anchor of Paramecium cross-reacting glycoproteins. Biochem. J. 253:395-400

15. Duszenko, M., Seyfang, A. 1993. Endocytosis and intracellular transport of variant surface glycoproteins in trypanosomes. In: Membrane Traffic in Protozoa. H. Plattner, editor. pp. 181-226. JAI Press, Greenwich, CT

16. Elwess, N.L., Van Houten, J. 1997. Cloning and molecular analysis of the plasma membrane $\mathrm{Ca}^{2+}$-ATPase gene in Paramecium tetraurelia. J. Eukar. Microbiol. 44:250-257

17. Eskandari, S., Wright, E.M., Kreman, M., Starace, D.M., Zamphighi, G.A. 1998. Structural analysis of cloned plasma membrane proteins by freeze-fracture electron microscopy. Proc. Natl. Acad. Sci. USA 95:11235-11240

18. Ferguson, M.A.J. 1992. Glycosyl-phosphatidylinositol membrane anchors: The tale of a tail. Biochem. Soc. Trans. 20:243-253

19. Flötenmeyer, M., Momayezi, M., Plattner, H. 1999. Immunolabeling analysis of biosynthetic and degradative pathways of cell surface components (glycocalyx) in Paramecium cells. Eur. J. Cell Biol. 78:67-77

20. Gerold, P., Vivas, L., Ogun, S.A., Azzous, N., Brown, K.N., Holder, A.A., Schwartz, R.T. 1997. Glycosylphosphatidylinositols of Plasmodium chabaudi chabaudi: a basis for the study of malarial glycolipid toxins in a rodent model. Biochem. J. 328:905911

21. Hansma, H.G. 1975. The immobilization antigen of Paramecium aurelia is a single peptide chain. J. Protozool. 22:257-259

22. Hjelmeland, L.M., Nebert, D.W., Osborne, J.C. 1983. Sulfobetaine derivatives of bile acids: nondenaturing surfactants for membrane biochemistry. Anal. Biochem. 130:72-82

23. Jones, I.G. 1965. Studies on the characterization and structure of the immobilization antigens of Paramecium aurelia. Biochem. J. 96: $17-23$

24. Kaneshiro, E.S., Beischel, L.S., Merkel, S.J., Rhoads, D.E. 1979. The fatty acid composition of Paramecium tetraurelia cells and cilia: Changes with culture age. J. Protozool. 26:147-158

25. Knochel, M., Kissmehl, R., Wissmann, J.D., Momayezi, M., Hentschel, J., Plattner, H., Burgoyne, R.D. 1996. Annexins in Paramecium cells. Involvement in site-specific positioning of secretory organelles. Histochem. Cell Biol. 105:269-281

26. Knoll, G., Braun, C., Plattner, H. 1991. Quenched flow analysis of exocytosis in Paramecium Cells: Time course, changes in membrane structure, and calcium requirements revealed after rapid mixing and rapid freezing in intact cells. J. Cell Biol. 113:1295-1304

27. MacIndoe, H., Reisner, A.H. 1967. Adsorption titration as semiquantitative assay for soluble and bound Paramecium serotypic antigen. Austr. J. Biol. Sci. 20:141-152

28. Miller, L.H., Good, M.F., Milon, G. 1994. Malaria pathogenesis. Science 64:1878-1883

29. Momayezi, M., Kersken, H., Gras, U., Vilmart-Seuwen, J., Plattner, H. 1986. Calmodulin in Paramecium tetraurelia. Localization from the in vivo to the ultrastructural level. J. Histochem. Cytochem. 34:1621-1638
30. Monteith, G.S.R., Roufogalis, B.D. 1995. The plasma membrane calcium pump-a physiological perspective on its regulation. Cell Calcium 18:459-470

31. Plattner, H. 1987. Synchronous exocytosis in Paramecium cells. In: Cell Fusion. A.E. Sowers, editor. pp. 69-98. Plenum Publishing, New York

32. Plattner, H., Lumpert, C.J., Knoll, G., Kissmehl, R., Höhne, B., Momayezi, M., Glas-Albrecht, R. 1991. Stimulus-secretion coupling in Paramecium cells. Eur. J. Cell Biol. 55:3-16

33. Plattner, H., Matt, H., Kersken, H., Haacke, B., Stürzl, R. 1984. Synchronous exocytosis in Paramecium cells. I. A novel approach. Exp. Cell Res. 151:6-13

34. Plattner, H., Miller, F., Bachmann, L. 1973. Membrane specializations in the form of regular membrane-to-membrane attachment sites in Paramecium. A correlated freeze-etching and ultrathinsectioning analysis. J Cell Sci. 13:687-719

35. Plattner, H., Wolfram, D., Bachmann, L., Wachter, E. 1975. Tracer and freeze-etching analysis of intracellular membrane-junctions in Paramecium. With a note on a new heme-nonapeptide tracer. Histochemistry 45:1-21.

36. Plattner, H., Zingsheim, H.P. 1983. Electron microscopic methods in cellular and molecular biology. Subcell. Biochem. 9:1-236.

37. Prat, A., Katinka, M., Caron, E., Meyer, E. 1986. Nucleotide sequence of the Paramecium primaurelia G surface protein. A huge protein with a highly periodic structure. J. Mol. Biol. 189:47-60.

38. Preer, J.R. 1959. Studies on the immobilization antigens of Paramecium. II. Isolation. J. Immunol. 83:378-384

39. Preer, J.R. 1986. Surface antigens of Paramecium. In: Molecular Biology of the Ciliated Protozoa. J. Gall, editor. pp. 301-339. Academic Press, London

40. Regoeczi, E. 1984. Iodine-Labeled Plasma Proteins, CRC Press, Boca Raton, FL

41. Schmidt, H.J. 1988. Immobilization antigens. In: Paramecium. H.-D. Görtz. Editor. pp. 156-166. Springer-Verlag, Berlin

42. Schwaller, B., Calef, E., Gitler, C. Rosenheck, K. 1993. Stimulusinduced association of $\mathrm{Ca}^{2+}$-binding proteins with the plasma membrane detected in situ by photolabeling of intact chromaffin and PC12 cells. Proc. Natl. Acad. Sci. USA 90:1295-1299

43. Simonds, W.F., Koski, G., Streaty, R.A., Hjelmeland, L.M., Klee, W.A. 1980. Solubilization of active opiate receptors. Proc. Natl. Acad. Sci. USA 77:4623-4627

44. Smith, T.M., Hennessey, T.M. 1993. Body plasma membrane vesicles from Paramecium contain a vanadate-sensitive $\mathrm{Ca}^{2+}$ ATPase. Anal. Biochem. 210:299-308

45. Sonneborn, T.M. 1974. Paramecium tetraurelia. In: Handbook of Genetics. C.R. Kung, editor. pp. 469-594. Plenum Press, New York

46. Sonneborn, T.M. 1975. The Paramecium aurelia complex of 14 sibling species. Trans. Am. Microsc. Soc. 94:155-178

47. Steers, E., Beisson, J., Marchesi, V.T. 1969. A structural protein extracted from the trichocyst of Paramecium aurelia. Exp. Cell Res. 57:392-396

48. Suzuki, K.M., Hayashi, N., Hosoya, N., Takahashi, T., Kosaka, T., Hosoya, H. 1998. Secretion of tetrain, a Tetrahymena cysteine protease, as a mature enzyme and its identification as a member of the cathespin L subfamily. Eur. J. Biochem. 254:6-13

49. VanHouten, J. 1998. Chemosensory transduction in Paramecium. Eur. J. Protistol. 34:301-307

50. Vilmart, J., Plattner, H. 1983. Membrane integrated proteins at preformed exocytosis sites. J. Histochem. Cytochem. 31:626-632

51. Völkel, H., Kurz, U., Lindner, J., Klumpp, S., Gnau, V., Jung, G., Schultz, J.E. 1996. Catepsin L is an intracellular and extracellular protease in Paramecium tetraurelia. Eur. J. Biochem. 238:198206 